\title{
An Analysis Of Mutual Fund Custodial Fees
}

Charles P. Cullinan, (Email: cullinan@bryant.edu), Bryant College

Dennis M. Bline, (Email: dbline@bryant.edu), Bryant College

\begin{abstract}
The Securities Exchange Commissions (SEC) has an ongoing initiative to examine mutual fund fees, and their disclosure to fund shareholders. Mutual fund custodial fees are usually paid directly to the custodian from fund assets, and can therefore affect fund performance and investor returns. The purpose of this paper is to develop and test a model of mutual fund custodial fees using both equity and bond funds. Regression analyses on bond and equity fund samples reveal that custodial fees result from a variety of factors, and that these factors differ between equity and bond funds. The results of this study can be a useful benchmark to evaluate the effectiveness of custodial fee management.
\end{abstract}

\section{INTRODUCTION}

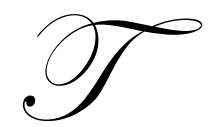

he cost structure of mutual funds has come under increasing scrutiny in recent years as both the number of mutual funds and their size have grown. The Securities Exchange Commission (SEC, 2000) has initiated a review of mutual fund fees and how they are disclosed. There has been some debate regarding whether fund fees are increasing or decreasing. Investment Company Institute papers have found decreasing shareholder cost ratios accompanying the growth of fund assets (e.g., Rea, et al. 1999; Rea and Reid, 1998) while studies by Morningstar and the SEC, using different methodologies, have found static or even rising shareholder cost ratios as mutual funds have grown in size (e.g., Cooley, 1999; Arnott, 1996; SEC 2000). The SEC has even considered a proposal which would require mutual funds to disclose to each shareholder the dollar cost the shareholder paid for fund investment management and administration (Brown, 2000). In an environment of cost consciousness, fund administrators may wish to better understand the nature of their costs, with a view toward opportunities for cost management.

The literature on fund expenses has focused either on the expense ratio as a whole, or on distribution fees. Those studies focusing on determinants of the whole expense ratio (e.g., Collins and Mack 1997; Malhotra and McLeod 1997; Latzko 1998; SEC 2000) provide information largely focused on the management fee, which is usually the largest proportion of the expense ratio. Trzinka and Zweig (1990) and the SEC (2000) develop models of the management fee directly. Research examining distribution fees (e.g., Livingston and O'Neal 1998; Chance and Ferris 1991) deals with shareholder expenses that typically are paid to an affiliate of the fund sponsor. The other individual components of the fund expense ratio have not been extensively examined, yet understanding the components of fund expenses may provide opportunities to more effectively manage fund expenses, and thereby raise investor returns.

One of the larger components of a fund's expense ratio (other than the management fee and distribution expenses) is the fee paid to the fund's custodian (Rae, et al. 1999). The duties of a custodian are to hold the securities of the fund, and to collect any income that these securities generate. Typically, the custodian is independent of the fund and the fund family.

The custodial fee is directly related to fund performance because the custodian is typically paid directly from fund assets. ${ }^{1}$ In addition, unlike management and distribution fees which are usually paid to a related party, the custodial fee is usually subject to arms-length negotiation with third parties. Therefore, careful management of custodial fees would not affect the financial performance of the fund sponsor, but could enhance the financial performance of the fund itself. 
The purpose of this paper is to empirically examine the nature of mutual fund custodial fees to provide a benchmark for such expenses, and to identify the factors that may influence the level of custodial fees. The remainder of this paper is organized into five sections. The next section develops a theoretical model of variables which may influence the custodial fee. This is followed by a discussion of the research methods used to empirically test the model, and the results of testing. The paper closes with implications of the results along with limitations of the research and a summary.

\section{DEVELOPMENT OF A MODEL OF CUSTODIAL FEES}

This section will review the fee model literature in the investment management industry, and adapt these models to custodial fees of mutual funds. The dependent variable is the fund's custodial fee ratio, defined as the custodial fee divided by total assets. The independent variables posited to relate to custodial fees fall into four basic categories: fund size, fund portfolio management, administrative structure of the fund, and the market position of the fund custodian.

\section{Size}

The size of a mutual fund is expected to be a significant variable influencing the level of the custodial fee. Most studies of mutual fund expense ratios have found that there is a negative relationship between fund size and the expense ratio (e.g., Rea et al. 1999) As funds increase in size, greater economies of scale are likely to exist, given that some portion of the custodial fee is likely to be fixed. Size in this study is measured using the log of assets, and is expected to be negatively related to the custodial fee ratio.

\section{Fund Portfolio Management}

There are five factors related to portfolio management decisions which will be considered in this section: number of securities held, portfolio turnover, fund yield, percentage of foreign securities, and percentage of the fund's assets in cash.

Securities held. A fund of a given size can be comprised of a differing number of securities. The SEC (2000) found that the number of securities held was associated with total fund expenses, but not with the management fees. This finding may result from the number of securities held being associated with a non-management-fee component of the total expenses, such as custodial fees. Because the major activity of custodians involves the holding of a fund's securities, a larger number of securities in the fund is expected to result in higher custodial fees. As such, a positive relationship is expected between the number of securities held and the custodial fee.

Portfolio Turnover. Mutual funds have widely varying portfolio management strategies regarding security holding periods. Previous research has found a relationship between portfolio turnover and fund expenses (e.g., Baumol, et al. 1990; Dellva and Olson 1998; SEC 2000). As securities are sold more frequently (i.e., portfolio turnover increases), the custodian is likely to incur greater cost in updating the records for the transactions. As such, there is expected to be a positive relationship between portfolio turnover and mutual fund custodial fees.

Fund yield. Malhotra and McLeod (1997) found a relationship between fund yield and fund expenses. As a mutual fund invests in more dividend and/or interest paying securities, the custodian is required to manage and report more transactions. These increased transactions will likely increase the custodian's costs and the custodial fee. The relationship between fund yield and custodial fee is expected to be positive.

Percentages of foreign securities and cash. Dellva and Olson (1998) and the SEC (2000) found a positive relationship between an international objective and fund expenses. Rea, et al. (1999, p. 5) suggests that "custody of foreign securities ... is considerably more expensive than custody of domestic issues." 2 As such, holdings of foreign securities will likely increase the custodial fee, leading to a positive relationship between the percentage of foreign securities held and the custodial fee. Conversely, holding cash is likely to decrease custodial expenses because cash typically represents just one asset (such as one repurchase agreement), or the fund may receive a credit from the 
custodian based on the uninvested cash. Evidence on the relationship between the percentage of cash and mutual fund expense ratios is mixed (e.g., Malhotra and McLeod 1997; Dellva and Olson 1998). A negative relationship is expected between the percentage of a fund's assets in cash and the custodial fee.

\section{Administrative Structure Of The Fund And The Fund Family}

There are four issues to be considered regarding the nature of the fund and the fund family: the number of custodians used, the size of the fund family, whether the custodian is related to the fund sponsor, and the expense ratio of the fund. The number of custodians used is likely to be positively related to custodial fees because a larger number of custodians suggest higher coordination costs. ${ }^{3}$ In addition, if there is some minimum fixed cost associated with having a custodian, the fixed cost will be incurred many times for a fund with many different custodians.

The size of the fund family could also affect the custodial fee in two ways. First, for a larger fund family, the cost of the fund family maintaining a relationship with a custodian ${ }^{4}$ will be spread over more funds, decreasing per fund expenses. Second, the custodian may be willing to discount their custodial fees to a large fund family to obtain the greater amount of business a larger fund family can provide. Previous research has found a negative relationship between complex size and the expense ratio (Malhotra and McLeod 1997; SEC 2000). Trzcinka and Zweig (1990) found a significant relationship between complex size and the management fee, although the SEC (2000) found no significant association between the number of funds in a fund family and management fee.

A limited group of mutual funds use custodians which are related to the fund sponsor. For example, many of the Putnam funds use Putnam Fiduciary (which is related to the fund sponsor) as their custodian. A related party may charge a higher custodial fee due to a lack of competition, although the effect of this relationship may be mitigated by the fund sponsor's fiduciary relationship with the fund shareholders. An indicator variable is included in the custodial fee model indicating whether the custodian is a related party. A positive relationship is expected between the related party custodian variable and the custodial fee.

The fund's overall cost consciousness could also be associated with the custodial fee. ${ }^{5}$ Some fund sponsors (e.g., the Vanguard Group) market their funds by emphasizing low fees. Other funds may not be as concerned about the fund's expense structure. If a fund were cost-conscious in other areas, they may also be concerned about minimizing custodial fees. As such, the expense ratio of the fund (with the effect of custodial fee on the expense ratio removed) is included in the custodial fee model, with an expected positive relationship with custodial fee.

\section{Market Position Of The Fund Custodian}

The position of the fund's custodian in the custodial marketplace could affect the fund's custodial fees in either a positive or a negative direction. Cullinan (1998) investigated audit fees of pension plans, and suggested that the expected relationship between market share of service providers and professional service fees was dependent largely on whether there was a perceived difference in quality based on greater market share. If there were no perceived quality difference, custodians with large market shares could spread their fixed costs over a large number of clients, resulting in a lower cost per client. Alternatively, a greater market share could provide a signal to the market of greater quality, permitting custodians with larger market shares to charge higher fees. Butler, et al. (1998/99) note that in difficult times clients prefer the "biggest and best" custodians, supporting the idea of quality differentiation based on size in the custodian market. Given the conflicting theories on the relationship between market share and fees, no directional prediction is made for this variable.

\section{RESEARCH METHODS}

\section{Sample}

Data for the current study were gathered from four sources. The Morningstar Principia Database was the source for many of the variables (i.e., fund assets, number of holdings, portfolio turnover, fund yield, percent of assets held in foreign securities, and percent of assets held in cash) while the fund's 1997 annual NSAR served as 
the source other variables (i.e., custodial fees, custodian name(s), and the number of custodians). The period examined was the fund's 1997 fiscal year. The size of the fund family was determined from Morningstar and The Wall Street Journal. The variable pertaining to custodian market share was an indicator variable for whether the primary custodian ${ }^{6}$ was one of the top 25 custodians in Institutional Investor's 1997 ranking of the top global custodians. See Table 1 for a description of the variables and an indication of the variables' sources.

TABLE 1

Description of Variables

\begin{tabular}{|c|c|c|}
\hline Variable & Operationalization & Data Source \\
\hline \multicolumn{3}{|l|}{ Dependent } \\
\hline Custodial fee/assets (in basis points) & Custodial fee/assets $* 1000$ & NSAR \\
\hline \multicolumn{3}{|l|}{ Independent } \\
\hline \multicolumn{3}{|l|}{ Fund Size } \\
\hline Log of assets & Log of fund assets & Morningstar \\
\hline \multicolumn{3}{|l|}{ Fund portfolio management } \\
\hline Number of securities held & $\begin{array}{c}\text { Integer indicating the number of securities held in the } \\
\text { fund }\end{array}$ & Morningstar \\
\hline Portfolio turnover & Portfolio turnover & Morningstar \\
\hline Fund yield & $\begin{array}{l}\text { Fund yield based on dividends and interest pain on } \\
\text { investments }\end{array}$ & Morningstar \\
\hline Percent of fund assets held in foreign securities & Percent of fund assets held in foreign securities & Morningstar \\
\hline Percent of fund assets held in cash & Percent of fund assets held in cash & Morningstar \\
\hline \multicolumn{3}{|l|}{ Fund administrative structure } \\
\hline Number of custodians & Integer indicating the number of custodians & NSAR \\
\hline Size of fund family & Number of funds in fund family & $\begin{array}{c}\text { Morningstar } \\
\text { \& Wall Street } \\
\text { Journal }\end{array}$ \\
\hline Related & $\begin{array}{c}1=\text { Custodian is a related party to the fund } \\
0=\text { Custodian is independent of fund }\end{array}$ & NSAR \\
\hline Adjusted expense ratio & (Total fund expenses - Custodial Fees)/Assets & $\begin{array}{l}\text { Morningstar } \\
\text { \& NSAR }\end{array}$ \\
\hline \multicolumn{3}{|l|}{ Custodian market position } \\
\hline Top 25 global custodian indicator variable & $\begin{array}{l}1 \text { if the custodian is one of the top } 25 \text { global } \\
\text { custodians, } 0 \text { otherwise }\end{array}$ & $\begin{array}{c}\text { Institutional } \\
\text { Investor } 1997 \\
\text { custodian } \\
\text { ranking }\end{array}$ \\
\hline
\end{tabular}

The Morningstar Database contains information for most publicly available mutual funds. Administratively, fund sponsors can establish a fund either as a separate legal entity or as a component of a trust which contains other funds. If a mutual fund is organized as a component of a larger trust, the data provided in the NSAR is subject to potential measurement error in that some of the information provided is for the trust of which the fund is a part, rather than for the individual fund itself. To avoid this measurement error, only funds which filed their own NSAR were included. Therefore, the sample for this study consists of those equity and bond mutual funds ${ }^{7}$ on the 1997 Morningstar Principia Database which were not organized as components of trusts.

Complete data were available on 321 equity funds and 164 bond funds. The median equity fund has a custodial fee of $2.2 \%$ of total fund expenses, while the median bond fund has custodial fees of $2.6 \%$ of assets. Additional descriptive statistics on the equity and bond funds are presented in Table 2. A preliminary view of the descriptive statistics leads to the observation that there are a number of practical differences between the equity funds and bond funds. The equity funds, on average, have a higher custodial fee, a larger dollar value of assets, a greater percentage of holdings in foreign securities, and a larger number of custodians. On the other hand, the bond funds, on average, have a higher portfolio turnover and a greater yield. These differences support separate analyses of equity and bond fund custodial expenses. 
TABLE 2

Descriptive Statistics mean/median/(standard deviation)

\begin{tabular}{|c|c|c|}
\hline & Equity fund (n=321) & Bond fund $(\mathrm{n}=164)$ \\
\hline Custodial fee (000) & $\begin{array}{c}\$ 309.20 \\
\$ 72.00 \\
(\$ 885.00)\end{array}$ & $\begin{array}{l}\$ 212.43 \\
\$ 39.50 \\
(\$ 789.64)\end{array}$ \\
\hline Fund assets $(000,000)$ & $\begin{array}{c}\$ 1216.98 \\
\$ 236.10 \\
(\$ 3392.30) \\
\end{array}$ & $\begin{array}{l}\$ 480.35 \\
\$ 178.00 \\
(\$ 953.68)\end{array}$ \\
\hline Number of securities held & $\begin{array}{c}107.01 \\
86.00 \\
(83.76) \\
\end{array}$ & $\begin{array}{c}95.28 \\
63.50 \\
(114.18) \\
\end{array}$ \\
\hline Portfolio turnover & $\begin{array}{c}84.79 \\
57.00 \\
(127.69) \\
\end{array}$ & $\begin{array}{c}122.98 \\
74.50 \\
(141.83) \\
\end{array}$ \\
\hline Fund yield & $\begin{array}{l}0.98 \% \\
0.64 \% \\
(1.19 \%)\end{array}$ & $\begin{array}{l}6.08 \% \\
5.94 \% \\
(1.20 \%)\end{array}$ \\
\hline Percent of fund assets held in foreign securities & $\begin{array}{c}25.54 \% \\
6.70 \% \\
(35.65 \%) \\
\end{array}$ & $\begin{array}{l}0.16 \% \\
0.00 \% \\
(1.32 \%)\end{array}$ \\
\hline Percent of fund assets held in cash & $\begin{array}{l}6.78 \% \\
4.80 \% \\
(7.45 \%) \\
\end{array}$ & $\begin{array}{c}6.46 \% \\
3.05 \% \\
(11.65 \%) \\
\end{array}$ \\
\hline Number of custodians & $\begin{array}{c}11.05 \\
1.00 \\
(23.65)\end{array}$ & $\begin{array}{c}5.92 \\
1.00 \\
(16.57)\end{array}$ \\
\hline Size of fund family & $\begin{array}{c}29.97 \\
21.00 \\
(29.04)\end{array}$ & $\begin{array}{c}36.04 \\
35.00 \\
(24.48)\end{array}$ \\
\hline Related party custodian & Yes $=6.8 \%$ & Yes $=4.7 \%$ \\
\hline Expense ratio (excluding custodial fee) in basis points & $\begin{array}{c}128.95 \\
111.36 \\
(146.34) \\
\end{array}$ & $\begin{array}{c}86.79 \\
84.28 \\
(79.82) \\
\end{array}$ \\
\hline Top 25 global custodian & Yes $=43 \%$ & Yes $=60 \%$ \\
\hline
\end{tabular}

\section{Analysis}

The model tested in the current study is as follows:

Custodial fee/assets (in basis points) $=a+b_{1} \log$ of assets $+b_{2}$ number of securities held $+b_{3}$ portfolio turnover $+b_{4}$ fund yield $+b_{5}$ percent of fund assets held in foreign securities $+b_{6}$ percent of fund assets held in cash $+b_{7}$ number of custodians $+b_{8}$ size of fund family $+b_{9}$ custodian related party $+b_{10}$ expense ratio (excluding custodial fees) $+b_{11}$ top 25 global custodian indicator variable Data for the current study were analyzed using regression analysis.

\section{RESULTS}

Tables 3 and 4 present the results of the regression models for the equity and bond fund samples, respectively. Both the equity and bond fund models have significant $F$ values (at 0.001 ). An analysis of variance inflation factors indicated no concerns with collinearity in either model, while residual analyses revealed no heteroschedasticity issues. Differences in the significance of the variables between the equity and bond fund models support the use of separate models for equity and bond funds. 
TABLE 3

Regression Results (Stock Mutual Funds)

Dependent variable: Custodial fee in basis points (based on total assets)

\begin{tabular}{|c|c|c|c|c|}
\hline \multicolumn{2}{|l|}{ Variable } & Parameter estimate & $\mathbf{t}$ & probability $>t$ \\
\hline \multicolumn{2}{|l|}{ Intercept } & 11.5019 & 10.69 & 0.0001 \\
\hline \multicolumn{5}{|l|}{ Fund Size } \\
\hline \multicolumn{2}{|c|}{ Log of assets (-) } & -1.6722 & -9.94 & 0.0001 \\
\hline \multicolumn{5}{|c|}{ Fund portfolio management } \\
\hline \multicolumn{2}{|c|}{ Number of securities held $(+)$} & 0.0081 & 1.99 & 0.0474 \\
\hline \multicolumn{2}{|c|}{ Portfolio turnover $(+)$} & 0.0038 & -1.64 & 0.1024 \\
\hline \multicolumn{2}{|c|}{ Fund yield (+) } & -0.3186 & -1.28 & 0.2017 \\
\hline \multicolumn{2}{|c|}{ Percent of fund assets held in foreign securities (+) } & 0.0297 & 3.38 & 0.0008 \\
\hline \multicolumn{2}{|c|}{ Percent of fund assets held in cash (-) } & -0.0391 & -1.00 & 0.3204 \\
\hline \multicolumn{5}{|c|}{ Fund administrative structure } \\
\hline \multicolumn{2}{|c|}{ Number of custodians $(+)$} & -0.0105 & -0.77 & 0.4446 \\
\hline \multicolumn{2}{|c|}{ Size of fund family (-) } & 0.0317 & 2.63 & 0.0091 \\
\hline \multicolumn{2}{|l|}{ Related (+) } & -0.0672 & -0.05 & 0.9567 \\
\hline \multicolumn{2}{|c|}{ Expense ratio (excluding custodial fee) in basis points $(+)$} & -0.0247 & -11.67 & 0.0001 \\
\hline \multicolumn{5}{|c|}{ Custodian market position } \\
\hline \multicolumn{2}{|c|}{ Top 25 global custodian indicator variable (?) } & 0.5474 & 0.85 & 0.3946 \\
\hline $\mathrm{n}$ & 321 & & & \\
\hline Adjusted $\mathrm{R}^{2}$ & 0.4338 & & & \\
\hline F Value & 23.29 & & & \\
\hline Prob $>$ F & 0.0001 & & & \\
\hline
\end{tabular}

TABLE 4

Regression Results (Bond Mutual Funds)

Dependent variable: Custodial fee in basis points (based on total assets)

\begin{tabular}{|l|c|c|c|}
\hline Variable & Parameter estimate & t & probability > t \\
\hline Intercept & 8.3276 & 5.83 & 0.0001 \\
\hline Fund Size & & & \\
\hline Log of assets (-) & -1.4257 & -6.25 & 0.0001 \\
\hline Fund portfolio management & & & \\
\hline Number of securities held (+) & 0.0038 & 1.24 & 0.2165 \\
\hline Portfolio turnover (+) & 0.0035 & 1.61 & 0.1086 \\
\hline Fund yield (+) & 0.5977 & 3.03 & 0.0029 \\
\hline Percent of fund assets held in foreign securities (+) & 0.1209 & 0.56 & 0.5745 \\
\hline Percent of fund assets held in cash (-) & 0.0042 & 0.17 & 0.8622 \\
\hline Fund administrative structure & & & 0.1272 \\
\hline Number of custodians (+) & -0.0276 & -1.53 & 0.5841 \\
\hline Size of fund family (-) & 0.0070 & 0.55 & 0.0828 \\
\hline Related (?) & 2.4088 & 1.75 & 0.0001 \\
\hline Expense ratio (excluding custodial fee) in basis points (+) & -0.0635 & -17.70 & \\
\hline Custodian market position & & & 0.0023 \\
\hline Top 25 global custodian indicator variable (?) & & 3.10 & \\
\hline $\mathrm{n}$ & & & \\
\hline Adjusted R & & & \\
\hline F Value & & & \\
\hline Prob > F & & & \\
\hline
\end{tabular}




\section{Equity Funds}

Table 3 presents the regression results for the equity sample. The model explained approximately 43 percent of the variation in equity fund custodial fees. The fund size independent variable (log of assets) has a significant $(\mathrm{p}<.0001)$ negative relationship with the custodial fee/assets variable. This finding is in accord with the theory that larger funds have economies of scale in their custodial fees. Implications of these results are that a fund which increases in size from $\$ 100$ million to $\$ 1$ billion in assets would experience a decrease in its custodial fee ratio of 3.83 basis points, which represents a savings from economies of scale of $\$ 38,300$ for the $\$ 1$ billion fund.

Two of the five fund portfolio management variables were significant at the $p<0.05$ level (number of securities held and percent of fund assets held in foreign securities). These results suggest that custodial fee is higher for funds investing is foreign markets, and for those with a larger number of securities held (given their asset size). These two findings were in the predicted direction. The remaining three fund portfolio management variables (i.e., portfolio turnover, fund yield, and percentage of assets in cash) were not significantly related to custodial fees for equity funds.

Of the four administrative structure independent variables, two are significant (at $\mathrm{p}<0.01$ ). The size of the fund family is significantly related to custodial fees. This direction of the relationship indicates that funds in larger fund families pay higher custodial fees. While this variable is significant, the direction of the relationship is not in accord with expectations. The expense ratio (excluding custodial fees) is also significantly associated with the fund's custodial fee. The negative coefficient for expense ratio implied that funds with larger expense ratios pay lower custodial fees. This relationship is also contrary to theoretical expectations. With regard to the market position of the custodian, whether the custodial fund is in the top 25 global custodians was not significantly related to the equity fund's custodial fees.

\section{Bond Funds}

Table 4 presents the regression results for the bond fund sample. The eleven independent variables explained 73 percent of the variation in bond fund custodial fees. The fund size variable (log of assets) had a significant $(\mathrm{p}<.0001)$ relationship with the custodial fees/assets. Consistent with the theorized direction, larger bond funds were observed to have a custodial fees which represent a smaller portion of total assets, which suggests economies of scale in bond fund custodial fees. For bond funds, as assets under management increased from \$100 million to $\$ 1$ billion, the custodial fee ratio would decrease by 3.27 basis points, which represents a savings from economies of scale of $\$ 32,700$ for the $\$ 1$ billion bond fund.

With regard to the five fund portfolio management variables, only fund yield was significantly related to custodial fees. Yield was positively related to custodial fees, consistent with the theorized direction. The other fund portfolio management variables were not significantly related to custodial fees.

Of the fund administrative structure independent variables, only the expense ratio (excluding custodial fees) is significantly related to custodial fees. As with the results from the equity fund model, the negative relationship is contrary to expectations. The custodian market position variable was positively related to custodial fees at $p=0.0023$. This finding suggests that custodians with large market shares may charge higher custodial fees in the bond fund market.

\section{DISCUSSION AND LIMITATIONS}

\section{Discussion}

The results presented support the notion that economies of scale exist in mutual fund custodial fees, whereby larger funds pay a smaller percentage of their assets in custodial fees. The most notable differences between the equity and bond fund results were related to the effects of portfolio management, and may reflect fundamental differences in the operations of bond and equity funds. Overall, the results provide only limited 
evidence in support of Rea, et al.'s (1999, p. 5) assertion that "the fee also reflects the complexity and scope of the custodial services." The different results from the equity and bond fund models for the securities held variable results may have been affected by the manner in which the variable was measured. For many bond funds, especially those investing heavily in US treasury securities, multiple treasury securities are often listed together when they have the same interest rate. As such, the number of securities held by bond funds may understate the number of securities held by funds focusing on US treasuries.

Fund yield was significant in the bond fund model, but not in the equity fund model. Yield is typically much higher for bond funds, which have income as a major objective, than for equity funds, which are usually less income oriented. The pricing of custodial services for equity funds may presuppose a lower level of income, thereby yield would not affect the fee. The portfolio turnover results provide mixed support for Rea et al.'s (1999) assertion that custodial fees are partially based on "... the volume of securities transactions" (p. 5). This assertion is supported for bond funds, but not for equity funds. Alternatively, yield may be associated with bond funds because higher yielding bonds may be those which are less liquid, resulting in higher custodial costs.

In both the equity and bond fund models, the expense ratio (excluding custodial fees) was negatively associated with custodial fees. This result implies that firms with higher expense ratios have lower custodial fee ratios, which was opposite to the predicted direction. One possible reason for this result is that firms which have higher non-custodial expenses may pressure the custodians to provide services at a lower price to avoid having their expense ratios become uncompetitively high.

Overall, the results suggest that the custodial fee is driven by many different factors, most of which related to the nature and operations of the fund. Also, the results indicate that the factors affecting custodial fees differ materially depending on whether the fund is primarily and equity or a bond fund. The models also provide a benchmark for assessing and predicting the custodial fees charged to mutual funds.

\section{Limitations \& Future Research}

The results presented in this study are subject to a number of limitations. Among these limitations are generalizability issues, and measurement issues. Due to the structure of NSAR filings, only funds which filed their own NSAR were included in the analysis. Those funds which are a component of a larger trust may have different characteristics than the funds included in this study, which may affect the generalizability of the results. In particular, this restriction may affect the fund family size variable. Future research could examine the possibility that custodial fees are related to the number of funds in a trust, rather than the size of the fund family because all the funds in the current sample are in a trust consisting of only one fund. Another limitation of the current research is the measurement of the number of securities held, especially for bond funds. As mentioned above, many bond funds group US treasury securities of the same interest rate into one line on the financial statement, potentially understating the number of securities held for those funds investing primarily in treasuries.

\section{CONCLUSIONS}

Given the current emphasis on mutual fund fee oversight and disclosure (e.g., SEC 2000) an examination of the components of mutual fund expenses is appropriate to provide a basis for assessing certain components of mutual fund fees. Custodial fees are usually the largest expense mutual fund administrators negotiate with nonrelated parties. This study examined variables which could help to explain variation in mutual fund's custodial fees. Results indicated that size was a major determinant of the custodial fee. Other factors hypothesized to impact custodial fees were found to have a significant correlation with equity fund or bond fund custodial fees, but not with both. These results underscore the importance of considering the distinctive nature of different type of funds when analyzing mutual fund fee structures.

The results of this study can be useful to fund directors as a benchmark in assessing the reasonableness of custodial fees. The results also provide evidence useful to fund investors regarding the economies of scale which can reduce the expense ratio of larger funds, potentially resulting in higher shareholder returns. 


\section{ENDNOTES}

1. A small group of fund families, such as the TIAA-CREF fund group, pay the custodian out of a comprehensive fee which they charge to the fund.

2. The SEC also notes that "Custody costs generally are higher" for international funds (p. 24).

3. Funds appear to use more than one custodian primarily when they have foreign operations.

4. Most fund families have their primary relationship with one custodian, or a limited number of custodians.

5. Cullinan (2002) found a positive relationship between expense ratio and the fund's audit fee.

6. When the fund had more than one custodian, the first custodian listed on the NSAR was used.

7. Equity and bond funds are considered separately due to their different operating characteristics.

\section{REFERENCES}

1. Arnott, A. C. The rising tide. Morningstar Mutual Funds, Summary Section, Vol, 28 No. 8, pp. S1-S2, 1996.

2. Baumol, W. J., S. M. Goldfield, L. A. Gordon, and M. F. Koehn. The Economics of Mutual Fund Markets: Competition Versus Regulation, Kluwer Academic Publishers, Norwell, MA, 1990.

3. Brown, K. GAO Urges Funds to Reveal Fees - Shift Could Spur Improved Prices. Wall Street Journal, July 6, 2000, p. C1.

4. Butler, R., A. Capon, and J. Marshall. The flight to quality continues in emerging markets sub-custody. Global Investor, Vol. 118, pp. 23-42, December 1998/January 1999.

5. Chance, D. M. and S. P. Ferris. Mutual fund distribution fees: An empirical analysis of the impact of deregulation. Journal of Financial Services Research, Vol. 5, pp. 25-42, 1991.

6. Collins, S. and P. Mack. The optimal amount of assets under management in the mutual fund industry. Financial Analysts Journal, Vol. 53, No. 5, pp. 67-73, 1997.

7. Cooley, S. Revisiting fund costs: Up or down? Morningstar Mutual Funds, Summary Section, Vol. 34, No. 6, pp. S1-S2, 1999.

8. Cullinan, C. P. SEC audit requirements and audit fees. Research in Accounting Regulation, Vol. 15, pp. 135-150, 2002.

9. Cullinan, C. P. Evidence of non-big 6 market specialization and pricing power in a niche assurance service market. Auditing: A Journal of Practice and Theory, Vol. 17, Supplement, pp. 47-57, 1998.

10. Dellva, W. L. and G. T. Olson. The relationship between mutual fund fees and expense and their effects on performance. The Financial Review, Vol. 33, pp. 85-104, 1998.

11. Institutional Investor. The world's largest global custodians. Institutional Investor, Vol. 31, No. 9, pp. 195196, 1997.

12. Latzko, D. A. Economies of scale in mutual fund administration. The Journal of Financial Research, Vol. 22, No. 3, pp. 331-339, 1999.

13. Livingston, M. and E. S. O'Neal. The cost of mutual fund distribution fees. The Journal of Financial Research, Vol. 21, No. 2, pp. 205-218, 1998.

14. Malhotra, D. K. and R. W. McLeod. An empirical analysis of mutual fund expenses. The Journal of Financial Research, Vol. 20 No. 2, pp. 175-190, 1997.

15. Rea, J. D., B. K. Reid, and K. W. Miller. Operating expenses, ratios, assets and economies of scale in equity mutual funds, Washington: Investment Company Institute, 1999.

16. Rea, J. D., B. K. Reid, and T. Lee. Mutual fund costs, 1980-1998, Washington: Investment Company Institute, 1999.

17. Rea, J. D. and B. K. Reid. Trends in the cost of equity mutual funds, Washington: Investment Company Institute, 1998.

18. Securities Exchange Commission (SEC). Division of Investment Management: Report on Mutual Fund Fees and Expenses, www.sec.gov/news/studies/feestudy.htm, (Visited 2/7/02) 2000.

19. Trzcinka, C. and R. Zweig. Monograph 1990-1: An Economic Analysis of the Costs and Benefits of S.E.C. Rule 12b-1, New York: Salomon Brothers Center for the Study of Financial Institutions, 1990. 
$\underline{\text { Notes }}$ 